\section{EREM 72/2}

Journal of Environmental Research, Engineering and Management Vol. 72 / No. 2 / 2016 pp. 31-55

DOI 10.5755/j01.erem.72.2.16183 (C) Kaunas University of Technology
Integrated Waste Management System for Resort Town

Received 2016/06

Accepted after revision 2016/09

\title{
Integrated Waste Management System for Resort Town
}

\section{Irina Kliopova}

Kaunas University of Technology, Institute of Environmental Engineering

K. Donelaičio 50-308, 44239 Kaunas, Lithuania

\author{
Corresponding author: irina.kliopova@ktu.lt \\ I. Kliopova, Kaunas University of Technology, Institute of Environmental Engineering \\ K. Donelaičio 50-308, 44239 Kaunas, Lithuania
}

Waste is an unused raw material or energy source. The Waste Framework Directive requires applying techniques for minimisation of environmental impact throughout the whole product life cycle, including such stages as product manufacturing and waste processing. During the last decade, all EU courtiers have been making every effort to decrease amounts of landfilled waste, applying different waste treatment techniques with the purpose to efficiently use material and energy potential of waste. Feasibility analysis of all alternatives, including environmental impact assessment and economical evaluation, is very important for selection of the best available option(s).

Waste management systems of all resort cities differ from other cities, in the first instance, due to the several times higher volume of generated municipal waste per capita and a number of disturbances for implementation of widely applied techniques, including prevention and source separation. Therefore, individual decisions have to be analysed in detail for each resort town. Palanga municipality - the biggest resort centre in Lithuania - was selected as a research object for detailed analysis. The paper presents the results of primary evaluation of the existing waste management system, including quantity and quality analysis of waste flows, and feasibility analysis of the options of source separation of biodegradable waste, including animal by-products from catering, alternatives of centralist processing of municipal waste after source separation and sewage sludge aerobic treatment. The most suitable solutions were suggested to improve environmental performance of the waste management system of Palanga municipality, applying integrated waste management methods. Only $14 \%$ of all the waste, generated in this resort would be disposed in a landfill after the implementation of the suggested options. Approximately $85 \%$ of biodegra-dable waste, including green waste from public territories, food waste or animal by-products from catering and sewage sludge would be used for the compost production for our purposes, growing of energetic plants or for composting parks and other public territories in Palanga resort. Certain solutions of the integrated waste management system can be successfully used in other resorts as well.

Keywords: integrated waste management, municipal waste, biodegradable waste, sewage sludge, feasibility analysis. 


\section{Introduction}

European Parliament and Council Directive 2008/98 / EC on waste (Waste Framework Directive) focuses on the criteria, according to which waste should be analysed as a resource (a secondary raw material or energy source). This is an attempt to ensure the efficiency of waste recycling, improving environmental performance and increasing cost-effectiveness. The Waste Framework Directive requires applying techniques for minimisation of environmental impact throughout the whole product life cycle and emphasises that the burning waste management methods should be used only for such separated waste which characterises good calorific value (Directive 2008/98 /EC).

Since 2008, all the EU countries have developed or updated National Waste Management Plans (NWMP), which provide the key tasks and measures for proper waste management with the purpose to prevent or/and minimise waste formation by applying cleaner production and pollution prevention methods, to use waste nutrients and energetic properties, and thus, to decrease the volume of disposed waste. NWMP's particular attention is given to municipal waste (MW) management solutions. According to the data of Eurostat, on overage $474 \mathrm{~kg}$ capita $^{-1}$ of MW was generated in EU-28 countries during 2014. Moreover, $27.8 \%$ of this waste was landfilled; over $27 \%$ became secondary raw materials (SRM), and $15.8 \%$ was biologically treated with the purpose to produce bio-energy and compost (Eutostat, 2016).

In Lithuania, already in 2011 , over $77 \%$ of MW was disposed. During the last years, the situation has radically changed due to improving source separation, implementation of green waste (GW) composting sites, private and municipal centralised mechanical treatment (MT) plants or mechanical/biological treatment (MBT) plants, and the combined heat and power plant in the city of Klaipeda, which uses non-hazardous municipal and industrial waste as fuel. Already in 2014, 21\% of MW was recycled, 9.5\% biologically treated, $8.8 \%$ used for energy production, and $58.9 \%$ landfilled (this part has to be significantly decreased before 2020). A number of works were performed with the purpose to minimise the volume of landfilled waste before implementation of the above mentioned techniques: different feasibility studies for selected suitable methods for MW, including municipal biodegradable waste (BDW), GW from public territories, and sewage sludge from municipal waste water treatment plants, management within all Lithuanian regions. Evaluations of environmental impact assessment (EIA), including the impact on human health assessment, were carried out for all the analysed methods. Lithuanian NWMP was prepared in 2010 and was corrected in 2014. During this period, each Lithuanian region has developed its own waste management plan (WMP), in which individual waste management decisions up to the year 2020 have been determined.

In Lithuania, BDW makes around 50\% of the total MW stream. Therefore, proper management of BDW is one of the most important questions in the waste management area. The priorities for municipal BDW management are the following: (1) management with the purpose to recover energy and nutrients; (2) management with the purpose to recover nutrients; (3) usage of waste flows, which remain after various treatment methods, for energy production (in case of this, waste is unsuitable for processing and has a good calorific value) (Lithuanian NWMP, 2014-2020). GW from gardens, green areas and parks must be collected and treated in centralised composting systems. In addition, the individual home composting of GW is to be promoted. The possibilities to separate municipal BDW and waste from public catering and settlements must be in detail analysed within all the regions (Lithuanian NWMP, 2014-2020).

The waste management system of any resort town differs from other towns due to the following most important reasons (Kliopova, 2013):

_ municipal waste and waste from public catering and settlements, the composition of which is similar to municipal waste, is made a core part of all the generated waste;

_ seasonality (especially in the Baltic Sea region, where each year, during the summer period a number of tourists increase considerably compared with the winter period);

_ the main part of the territory is recreation areas, cultural and natural heritage sites, Natura 2000 territories, etc., in which any centralised municipal waste management activity is not permitted (waste has to be transported on long distance, 
and, therefore, the price for MW management is increased);

- limits for source separation activity (few available areas, which belong to municipality, difficult driveway for waste collection vehicles, high land-tax);

- the main part of MW is BDW; therefore, during the tourist season (namely, in the warm season), containers have to be emptied more often, because of odour emissions; besides, MW management costs are significantly increased;

- vacationers during their holidays put less attention on such aspects as sort separation of secondary raw materials (SRM) or BDW;

- cost of MW management for residents is much higher in comparison with cost in other towns (firstly, due to the several times higher volume of generated municipal waste per capita).

Palanga municipality was selected as a research object for the detailed analysis. Research was started in 2012-2013, when implementing one stage of the RECO Baltic 21 Tech project. The overall objective of this project was to improve the local and regional capacity to apply the process of implementing waste management that supports the implementation of the Waste Framework Directive, helping courtiers in the Baltic Sea Region to address their problems with waste management and disposal (RECO Baltic 21).

The aim of the research in Palanga municipality (Palanga resort) was to determine the main problems of the existing waste management system and to suggest the most suitable solutions to improve environmental performance by integrated waste management methods. Further research was extended in 2015-2016 with the purpose to pay more attention to source separation of BDW and select the best available method for secondary centralised MW treatment after increasing the cost for MW delivery and disposal ('landfill tax') in all Lithuanian regions.

\section{Materials and methods}

The main stages of research, which correspond to the research targets, applied methods, and expected results, are presented in Fig. 1.
The mass balance principle was applied for the evaluation of separate fraction of mixed MW:

$$
M=M_{B D W}+M_{S R M}+M_{H W}+M_{C B W}+M_{S h}+M_{O C W}+M_{O N W} \text {, }
$$

where

$M$ - mass of mixed MW, tonnes year ${ }^{-1}$;

$M_{B D W}$ - mass of BDW (food waste, including animal by-products, GW, paper and cardboard waste and packaging, natural textile waste), tonnes year ${ }^{-1}$;

$M_{S R M}$ - mass of SRM, including glass and glass packaging, metal waste and packaging, plastic waste and packaging, and not including paper and cardboard waste and packaging, tonnes year- ${ }^{-1}$; $\mathrm{M}_{\mathrm{HW}}$ - mass of hazardous waste, including electronic, tonnes year ${ }^{-1}$; $M_{C B W}$ - mass of constriction and bulky waste, tonnes year ${ }^{-1}$; $M_{\text {sh }}$ - mass of shorts, tonnes year ${ }^{-1}$;

$M_{\text {ocw }}$ - mass of other, combustible waste, tonnes year ${ }^{-1}$;

$M_{\mathrm{ONW}}$ - mass of other, non-combustible waste, tonnes year ${ }^{-1}$.

Mass of separate fraction (i) of mixed MW (tonnes year ${ }^{-1}$ ) was evaluated using equation (2):

$$
M_{i}=M \times k_{i},
$$

where

$k_{i}$ - part of fraction (i) within the mixed MW $\left(0>k_{i} \leq 1\right)$, which was evaluated by weighing during the experiment in Palanga resort; weightings were carried out 4 times per year (in different seasons) in 2012-2013 by representatives of the waste management centre of Klaipeda region and Palanga Municipality.

Almost all of the MW flows, evaluated by equation (1), can be processed by source separation or centralised MW treatment methods. The amount of separate fraction (i) (tonnes year-1), processed by source separation, can be estimated using equation (3):

$$
M_{i 1}=M \times k_{i} \times k_{i 1}
$$

where

$k_{i 1}$ - source separation efficiency for fraction (i) $\left(0>k_{i 1} \leq 1\right)$. 
Fig. 1

Main stages of research

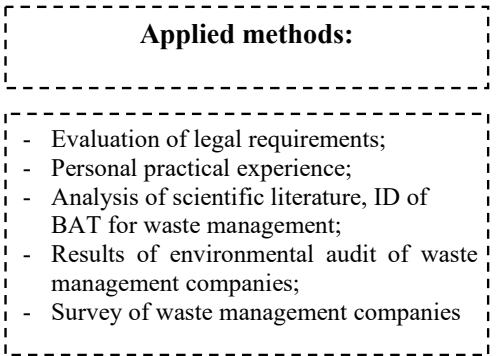

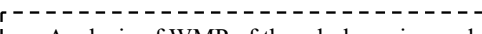
Analysis of WMP of the whole region and resort individually;

- Quantity evaluation of waste flows (experiments, statistic and accounting data, theoretical evaluation, etc.);

- Quality evaluation of waste (laboratory analysis, theoretical evaluation, etc.)

- Survey of local waste management companies

I

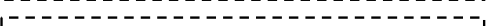

- Waste management hierarchy;

- Integrated waste management methods

(from prevention to recycling);

- Material and energy balance;

- Best available techniques (BAT) for

waste management;

Feasibility analysis:

Technical evaluation;

Environmental evaluation;

Economical evaluation;

Evaluation of environmental performance by indicator system; Comparative analysis;

Etc.

\section{Main stages of the research:}

1. Analysis of primary and secondary techniques, applied for reduction of disposed MW

\footnotetext{
3.1 Suggestion of methods for improving source separation and its feasibility analysis
}

3.2 Suggestion of options of centralised processing of rest MW flow and its feasibility analysis

3.3 Suggestion of sewage sludge management options and its feasibility analysis

4. Suggestion of an integrated waste management system (IWMS) for the resort city

Achieved results:

- Set of widely applied and novelty methods of processing MW, including BDW, GW, animal by-product, etc.;

- Technical aspects of waste processing processes (e.g., efficiency; indicators of energy, water consumption, resulted emissions, etc. per unit of processed waste; advantages and disadvantages of some techniques, etc.)

- Amounts and characteristics of all waste flows, including composition of MW, laboratory analysis of sewage sludge, etc.;

- List of local waste management companies;

- Main problems of the existing waste management system and their reasons;

- Main targets for waste processing by means different than landfilling

- Set of suitable source separation methods (for households, catering, etc.);

- Expected economic effect and environmental benefits

- Best available option for MW centralised processing;

- Expected economic effect and environmental benefits

- Best available option for sewage sludge management (processing);

- Expected economic effect and environmental benefits

- IWMS;
$-\quad \begin{aligned} & \text { Expected economic, environmental and social } \\ & \text { benefits due to implementation of IWMS tasks }\end{aligned}$

It is very important to evaluate the composition of $\mathrm{MW}$ after source separation before selecting a suitable option of MW centralist processing. The amount of separate fraction (i) of MW after source separation, which will be further processed in MT or MBT, can be estimated using the following equation:

$$
\begin{aligned}
M_{i M B T}= & M_{i}-M_{i 1}=M \times k_{i}-M \times k_{i} \times k_{i 1}= \\
& M \times k_{i} \times\left(1-k_{i 1}\right)
\end{aligned}
$$

Preliminary volume of remaining separate fraction (i) of $\mathrm{MW}\left(\mathrm{M}_{\text {iout }}\right.$, tonnes year $\left.{ }^{-1}\right)$ after source separation and centralist processing can be estimated using the following equation:

$$
M_{\text {iout }}=M_{i}-M_{i 1}-M_{i 2}=M \times k_{i} \times k_{i 2} \times\left(1-k_{i 1}\right),
$$

where

$\mathrm{k}_{\mathrm{i} 2}$ - efficiency of centralist processing of fraction (i) in MT or $\operatorname{MBT}\left(0>\mathrm{k}_{\mathrm{i} 2} \leq 1\right)$. 
Practically, in case of source separation and MBT, $M_{\text {out }}$ has to be less than $15 \%$ of the total mass of generated MW. The largest proportion of the remaining waste consists of non-combustible small fraction.

The following chemical and physical parameters of sewage sludge were analysed in the Agrochemical Research Laboratory of the Lithuanian Research Centre for Agriculture and Forestry: moisture content (\%), net calorific value as received and in dry matter $\left(\mathrm{MJ} \mathrm{kg}^{-1}\right)$, content of organic material (OM), S, N, C, P, Cl, and content of all heavy metals $(\mathrm{Zn}, \mathrm{Pb}, \mathrm{Cd}, \mathrm{Cu}, \mathrm{Cr}, \mathrm{Ni}, \mathrm{Hg})$ in dry matter (\%). Microbiological-parasitological pollutions, such as number of colonial of faecal coliforms (E. coli) (number $\mathrm{g}^{-1}$ ), anaerobic clostridia (number $\mathrm{g}^{-1}$ ), pathogenic enterobacteria (units $\mathrm{g}^{-1}$ ), and units of Helminth eggs and larvae (units $\mathrm{kg}^{-1}$ ), were determined in the National Public Health Laboratory.

The method applied to evaluation of the net calorific value $\left(\mathrm{kJ} \mathrm{kg}^{-1}\right)$ of solid recovered fuel (SRF), made of separated fraction of primary compost (Kliopova \& Makarskienè, 2015) is as follows:

$$
Q_{\text {net }}{ }^{d r y}=Q_{\text {gross }}{ }^{d r y}-2441 \times(9 \times H / 100),
$$

where

$Q_{\text {gross }}{ }^{\text {dry }}$ - higher calorific value (gross) in dry matter was measured with a bomb calorimeter, $\mathrm{kJ} \mathrm{kg}^{-1}$;

$\mathrm{H}$ - hydrogen content in dry matter, \% $(\mathrm{H}=6 \%)$;

$$
Q_{\text {net }}^{\text {as received }}=\left[Q_{n e t}{ }^{\text {dry }} \times(100-W)-2441 \times W\right] / 100
$$

where

$Q_{\text {net }}$ as received - net calorific value in as received, $\mathrm{kJ} \mathrm{kg}^{-1}$;

W - moisture content, \%.

The evaluation of removable (evaporated) water volume $\left(m_{\mathrm{H} 2 \mathrm{O}}\right)$ from sewage sludge and theoretical evaluation of energy, required for this process, were done using equation (8):

$$
m_{\text {H20 }}=m \times\left(W_{1}-W_{2}\right) /\left(100-W_{2}\right),
$$

where

$\mathrm{m}$ - mass of sewage sludge before drying/dewatering, tones year-1;

$\mathrm{W}_{1}$ - moisture content of sewage sludge before drying/dewatering, \%;

$\mathrm{W}_{2}$ - moisture content of sewage sludge after drying/dewatering, \%.

Other research methods are presented in Fig.1

\section{Results and discussion}

\section{Widely applied techniques for minimisation of municipal waste landfilling}

Widely used primary MW management methods in EU countries (within households):

- Source separation of SRM by use of different methods of a collection system: separate containers, different colour packages, deposit system for one-way beverage packaging, etc.;

_ Home composting of GW (garden and green food waste) in individual households and, thus, production of rather good quality compost and its usage for personal purposes (Kliopova \& Knašyte, 2012, Klipova \& Stanevičiūtè, 2013);

- Source separation of municipal BDW and delivery by BDW (including animal by-products) managers, which use this waste as raw materials for production of new products (fodders, biogas, compost, etc.). Different methods can be used for this purpose, depending on the selected collection system: separate containers, different colour packages, centralised collection, etc.

Widely used methods of BDW management in catering companies:

- Management of animal by-products according to requirements, presented in Chapter I of Annex VIII of Commission Regulation (EU) No 142/2011: storage in special separate tanks and/or refrigerators by applying special temperature regimes: in case of $\geq+7^{\circ} \mathrm{C}$, animal by-products can be stored for maximum 3 days; in case of $0^{\circ} \mathrm{C}$ for 7 days, and up to 30 days if temperature $\leq-10^{\circ} \mathrm{C}$ 
(Regulation (EU) No 142/2011, Regulation (EC) No 1069/2009);

_ Collecting in special tanks and using probiotics, e.g., SCD Odor Away for minimisation of odour emissions and transferring to BDW (including animal by-products) management companies (e.g., 1 time per week) (AVAI);

_ Intensive composting with additional energy consumption (if a separate room for equipment instillation is available in order to avoid crosscontamination) and production of compost or primary compost (depending on the selected technology) (BioWaste Technologies).

Composting separated BDW or, first of all, anaerobic treatment with the purpose to produce biogas and further composting of generated digestate with GW with the purpose to produce good quality compost are the most popular separated municipal BDW management methods. During the composting process, waste mineralises due to complex biological, biochemical and physical processes, bioorganic elements get free, and, thus, humus is formed. Natural compost is not only a valuable fertiliser, but also a kind of stimulus for soil vitality (AVAI). Many countries use compost as a fertiliser with quality requirements, which are presented in Standard CEN/TC 223 Soil improvers and growing media. In 2011 , researchers of the Agrochemical Research Laboratory of the Center of Lithuanian Agriculture and Forestry Science (LAMMC) suggested ranking some indicators of produced compost as a fertiliser. They suggested assessing compost quality by 2 aspects: from the safety point of view and compost as a fertiliser. According to this research work, the value of compost may be very low, low, medium, high, and very high (Staugaitis et al., 2011, 2015, Kliopova \& Stanevičiūtè, 2013). Quality compost with medium, high, and very high value can be produced only from source separated municipal BDW, including animal by-products.

A considerable amount of BDW, SRM and combustible fraction (RDF - refuse-derived fuel for SRF - solid recovered fuel production) remains in MW stream after source separation. The material and energy potential of the remaining $\mathrm{MW}$ can be recovered by different techniques, which are widely applied in centralist mechanical treatment (MT) and/or mechanical/biological treat- ment (MBT) plants (Eunomia et al. 2002, EPEM).

There are 2 alternatives of mechanical treatment of $\mathrm{MW}$ in MT or MBT: intensive separation of SRM and/or RDF fractions with efficiency up to $90-95 \%$, and semi-automatic separation with efficiency $60-80 \%$ (depending on waste flow). There are several alternatives of biological treatment of MW in MBT (EPEM):

- Fermentation - anaerobic treatment, produced biogas, followed by further digestate processing or composting. There are 3 main classifications of anaerobic digestion techniques, which depend on moisture content of MW: wet (up to $85 \%$ ), dry (up to $80 \%$ ), and completely dry (up to 50-60\%) (Gujer et al., 1983, Karagiannidis \& Perkoulidis, 2009, BEKON Energy Technologies).

_ Aerobic treatment of MW or digestate after MW fermentation, which afterwards can be applied as technical compost, for example, for overlay of landfills' layers, covering of dumping sites, and other land remediation purposes. Intensive composting with automatic process control by using the tunnel (containers, boxes) system is widely used for this purpose. The main aspects for choosing are the following: short duration of primary compost production (3-4 weeks); a small area of land required $\left(0.1-0.2 \mathrm{~m}^{2}\right.$ tonne ${ }^{-1}$ of BDW) (Cadena et al., 2009); minimisation of air emissions $\left(\mathrm{NH}_{3}, \mathrm{VOC}, \mathrm{PM}, \mathrm{CO}\right)$ and $\mathrm{GHG}$ emissions $\left(\mathrm{N}_{2} \mathrm{O}, \mathrm{CH}_{4}, \mathrm{CO}_{2}\right)$ from 50 to $99 \%$, thus, minimising odour (Clemens \& Cuhls, 2003, Amlinger et al., 2008); and elimination of risks of microbiological pollutants due to temperature automatic control.

_ Biological treatment of the whole MW stream, using the principles of bio-drying. Subsequently, RDF faction is separated from the remaining mass (Velis et al., 2009).

According to Article 14 of Council Directive 98/15/EEC amending Directive 91/271/EEC concerning the urban wastewater treatment, 'sludge arising from wastewater treatment shall be re-used whenever appropriate.' The following aspects have to be evaluated for the choice of suitable sewage sludge processing technology: volume of generated sewage sludge, physical and chemical characteristics of sewage sludge, geographic and climatic conditions of the region, technical and legal 
possibilities to use waste heat energy or energy from alternative energy sources (AES), deficiency of AES within the region, humus layer in region, etc. (Kliopova, 2013).

Widely use methods of urban sewage sludge processing in Lithuania and other EU countries:

- Biochemical treatment. Methane and alcohol fermentation, produced biogas $\left(0.4-0.74 \mathrm{~m}^{3} \mathrm{~kg}^{-1}\right.$ of dry matter (DM) of sewage sludge with $60-75 \%$ of methane concentration, which can be increased up to $96 \%$ by various treatment methods) followed by further digestate processing: dewatering and composting with GW or drying for SRF and/ or compost production (Monnet, 2003, Busca \& Pistarino, 2003, Haandel et al., 2007);

_ Composting with GW, using different technologies: open composting system, using tumblers; intensive composting, e.g., aerated windrow cover system with a special film made of LDPE, GoreTex material (Biodegma, Gore Cover), and a tunnel (containers, boxes) system.

The EU Sewage Sludge Directive 86/278/EEC and the Lithuanian normative document LAND 20-2005 Requirements for sewage sludge use for reutilization and remediation prohibit the use of untreated sewage sludge on agricultural land. These documents set the limit values for heavy metals and organic compounds to avoid bioaccumulation in plants and animals; moreover, the usage of sewage sludge in agriculture is prohibited in case the concentrations of heavy metals in the soil exceed both the indicated limits and/or the limits of sewage sludge load quantity. Requirements of LAND 20-2005 are constantly revised, mostly tightening and adding new controlled parameters. For this reason, the application of sewage sludge and sewage sludge compost to agriculture is decreased, i.e. the existing soil contamination hinders its usage (Kliopova \& Makarskienè, 2015).

Therefore, sewage sludge is increasingly analysed as an energy source or raw material for fuel production, by applying different methods. Volume and mass reduction, thermal destruction of toxic organic pollutions and energy recovery from organic matter are the main advantages of thermal processes (Ye et al., 2012; Magdziarz and Werle, 2014). Combustion is a very simple tech- nique for energy recovery from sewage sludge. Dried sewage sludge can be used as an SRF with net calorific value from 9 to $17.5 \mathrm{MJ} \mathrm{kg}^{-1}$ of sludge (in dry matter) (Houdkova et al., 2008; Kliopova \& Makarskienè, 2012). Unfortunately, a lot of energy has to be used for fuel preparation. Practically, energy consumption amounts up to $750-1500 \mathrm{kWh} / \mathrm{t}_{\mathrm{H} 2 \mathrm{O}}$ and depends on the used drying technology (Berghel, Renström, 2003, Spets, Ahtila, 2004, Holmberg, 2007, Li et al., 2011). Therefore, additional energy sources must be used for sludge drying. In Lithuanian wastewater and sewage sludge management companies, which have chosen this method, natural gas combustion plants are widely used for these purposes. Besides, a rather big ash content (up to 39\%) is one of the negative characteristics of sewage sludge (Cukjati et al., 2012, Kliopova \& Makarskiene, 2012). Researchers suggest various methods for optimisation of SRF production or combustion processes with the purpose to increase energy recovery:

_ sewage sludge dewatering and common combustion with MW (without drying) (Xiao et al., 2010);

_ dried sludge combustion with MW, wood residues and coal, and waste energy usage for sludge drying without additional energy (Xiao et al., 2010); SRF production from sewage sludge, wood residues, and BDW from food industry (Wzorek, 2012);

- SRF production from separate fraction of precomposted materials (sewage sludge and biomass residues) (Kliopova \& Makarskienè, 2012, 2013, 2015), etc.

\section{Main results of primary evaluation of MW management in Palanga resort}

Palanga is the biggest resort centre in Lithuania, situated near the Baltic Sea in Klaipeda region. The population of approximately 15.7 thousand people reside in a territory of approximately 7.9 thousand ha, which includes $32.7 \%$ of forest and park areas. More than 220 accommodations and over 100 catering companies operate in this resort. More than 300 thousand tourists visit this resort yearly. The results of initial analysis of the existing waste management system of Palanga, which was carried out in 2012, show that (Kliopova, 2013):

_ In 2011, over 20 thousand tonnes year-1 of waste 
were generated, including over 16 thousand of mixed MW (or $958 \mathrm{~kg}$ capita $^{-1}$ ). Over $50 \%$ of MW is municipal BDW. Besides, $90 \%$ of MW is generated during the tourist season (from the middle of March to the end of November). The maximum amount of MW is up to 2.7 thousand tonnes month $^{-1}$. Approximately $60 \%$ of $\mathrm{MW}$ is collected from individuals, and $40 \%$ from legal persons, including catering and accommodation companies. Approximately $78 \%$ of MW was delivered to the regional landfill, which is located approximately 35 $\mathrm{km}$ from Palanga.

_ GW from public territories, including seaweeds (up to 2,300 tonnes year ${ }^{-1}$ ), was collected and transported to the special GW site in Glaudenai village. It was planned that additionally a new GW site $(\mathrm{S}=0.78 \mathrm{ha})$ with a capacity of 2.8 thousand tones year-1 ${ }^{-1}$ would be implemented on the territory of the old landfill in Joskaudai village ( $7 \mathrm{~km}$ from Palanga).

- Source separation of SRM from MW stream started in 2011. Over 83 SRM collection sites have already been implemented.

- 1.5 thousand tonnes year ${ }^{-1}$ of sewage sludge are generated after biological wastewater treatment and dewatering up to $20 \%$ of dry matter (DM) by mechanical press and accumulated in the special storage site (polygons) in the territory of wastewater treatment plant 'Palangos vandenys' Ltd. Since 1993, a big amount of sewage sludge (about 9 thousand tonnes) has been collected.

In accordance with the norm of Lithuanian regulatory document LAND 20-2005, this sewage sludge is attributed to categories I and II according to content of heavy metals and to classes $A$ and $B$ according to microbiological-parasitological pollutions. The total heavy metal concentration in Palanga sewage sludge is from 1.5 to 2.1 times lower than that of sewage sludge in other EU countries (see Table 2). This can be explained by the absence of manufacturing in the municipality. The relatively low metal content increases possibilities to use the processed sewage sludge. During the experiment, the wastewater treatment plant focuses on the dewatered sewage sludge usage for energetic plant composting. In this case, the sewage sludge management cost was around 9 EUR tonne $^{-1}$. The company has analysed the possibility to deliver dewatered sewage sludge to a bigger sewage sludge treatment plant, which is located over $50 \mathrm{~km}$ from polygons. In this case, the total sewage sludge management cost will amount to over 60 EUR tonne ${ }^{-1}$ of sewage sludge.

In accordance with Lithuanian NWMP for 2014-2020, accumulation of urban sewage sludge in polygons was stopped in 2015.

The prognosis of MW generation and composition in Palanga and its management targets up to 2020 are presented in Table 1. In total, 9.6 thousand tonnes year ${ }^{1}$ of MW, including over 8 thousand tonnes year ${ }^{1}$ of BDW have to be managed by means different than landfilling.

According to the data of the waste management plan of Klaipeda region for 2014-2020 (Klaipeda WMP), since 2016, the landfill tax ('gate' fee) for MW from Palanga resort amounts to 36.37 EUR tonne ${ }^{-1}$, including $21 \%$ of VAT; the 'gate' fee for GW is 17.52 EUR tonne $^{-1}$, including VAT. It should be noted that the tax for GW composting in other Lithuanian regions exceeds 50 EUR tonne $^{-1}$.

\section{Main results of feasibility analysis of MW management options}

The following questions were analysed during this stage of research:

_ the methods for improvement of source separation of SRM and BDW, including green waste home composting in individual households, using composting bins, management of BDW (animal by-products) in catering companies, including accommodations, kindergartens, schools, etc.;

_ the implementation of a centralised mechanical (MT) or mechanical/biological treatment (MBT) system on the part of the territory of the old landfill (near GW centralised composting site) and delivery of the remaining waste to the regional landfill and/ or incineration plant (in Klaipeda).

GW (garden and green food waste) home composting is one of the most environmentally friendly and economically useful techniques of GW management. Lithuania has old traditions of GW composting, e.g., mulching is one of the most popular, especially in rural areas. Use of modern composting bins is a more suitable solu- 


\begin{tabular}{l|c|c}
\hline \multicolumn{1}{|c|}{ Composition of municipal waste (MW) } & \multicolumn{2}{c}{${ }^{12020}$} \\
\cline { 2 - 3 } & $\begin{array}{c}2 \% \text { of the } \\
\text { total MW }\end{array}$ & ${ }^{3}$ tonnes year $^{-1}$ \\
\hline Food waste & 2 & 3 \\
\hline Green waste, including from public territories & 21 & 4,030 \\
\hline Paper and cardboard waste and packaging & 21 & 3,900 \\
\hline Natural textile & 7 & 1,400 \\
\hline Total BDW & 2 & 460 \\
\hline Glass and glass packaging & 51 & 9,790 \\
\hline Metal waste and packaging & 5 & 960 \\
\hline Plastic waste and packaging & 3 & 580 \\
\hline Hazardous waste, including electronic & 11 & 2,100 \\
\hline Construction and bulky waste & 1 & 190 \\
\hline Shorts & 5 & 960 \\
\hline Other combustible waste & 3 & 600 \\
\hline Other, non-combustible waste & 11 & 2,100 \\
\hline Total MW & 10 & 1,920 \\
\hline MW management target (waste treated by means different than landfilling) & 50 & 19,200 \\
\hline The possible amount of BDW to landfill (NWMP, 2014-2020) & $\mathbf{9 , 6 0 0}$ \\
\hline BDW management target (without disposal to the landfill) & $\mathbf{5 0}$ \\
\hline \hline
\end{tabular}

\section{Table 1}

Composition of MW in Palanga resort (prognosis and management targets for 2020)

\section{Notes:}

${ }^{1} \mathrm{MW}$ growth up to $2 \%$ per year was evaluated.

${ }^{2}$ Composition of MW was evaluated by weighing during the experiment in Palanga resort (2012-2013).

${ }^{3}$ Mass of separate fractions is evaluated using equation (2).

\begin{tabular}{c|c|c|c|c}
\hline \multirow{2}{*}{ Heavy metal } & \multicolumn{4}{|c}{ Heavy metals in sewage, $\mathrm{mg} \mathrm{kg}^{-1}$ (DM) } \\
\cline { 2 - 5 } & Category I (LAND 20-2005) & Category II (LAND 20-2005) & Palanga resort & 'EU average \\
\hline $\mathrm{Pb}$ & 2 & 3 & 4 & 5 \\
$\mathrm{Cd}$ & $<140$ & $140-750$ & $15-24$ & 56.73 \\
$\mathrm{Cr}$ & $<1.5$ & $1.5-20$ & $1-4$ & 1.68 \\
$\mathrm{Cu}$ & $<140$ & $140-400$ & $18-24$ & 150.00 \\
$\mathrm{Ni}$ & $<75$ & $75-1,000$ & $10-125$ & 376.98 \\
$\mathrm{Zn}$ & $<50$ & $50-300$ & $12-23$ & 80.00 \\
$\mathrm{Hg}$ & $<300$ & $300-2,500$ & $800-1,000$ & 1157 \\
\hline \hline
\end{tabular}

Table 2

Palanga sewage sludge categorisation based on heavy metal concentrations

Note:

'Information source: database (Obernberger et al., 2009). 
tion for individual households in cities, especially resorts. Commonly used composting bins are (Kliopova \& Stanevičiūtè, 2013):

_ closed bins (with capacity 0.6-1.2 $\mathrm{m}^{3}$ ): diversiform, design decisions, some of them improved, e.g., with a mixing system, or with 2 or 3 chambers ( $1^{\text {st }}$ for BDW stirring, $2^{\text {nd }}$ for composting and primary compost production, and $3^{\text {rd }}$ for compost maturation);

- closed containers with additional warming (for composting all BDW from MW stream, including animal by-products);

_ special bins for vermin-composting: composting, using various worms, usually red wigglers, to create a heterogeneous mixture of BDW, etc.

On the average, up to $450 \mathrm{~kg}$ of BDW per household (2-5 residents, 0.06-0.1 ha) can be collected and composted during 1 composting season using a composting bin with the capacity of $700 \mathrm{~L}$, and about $225 \mathrm{~kg}$ of compost can be produced and used therein for domestic purposes (Kliopova \& Stanevičiūtè, 2013). Approximately 1,400 individual households are situated in Palanga resort. According to the data of Palanga waste management plan for 2014-2020 (Palanga WMP), since 2013, over 520 composting bins for green waste home composting have been distributed for residents. Therefore, during further analysis, it was assumed that minimum 0.3 thousand tonnes year ${ }^{-1}$ of GW in Palanga resort would be managed by home composting.

Three possibilities for the management of source separation of BDW (including animal by-products) within catering companies were evaluated:

- separate, store in a refrigerator $\left(\geq+7^{\circ} \mathrm{C}\right)$, and $1-2$ times per week deliver to any animal by-products' management companies (e.g., 'Branda' Ltd. - a compost production company, which operates in Klaipeda region);

_ separate, store in special tanks, using probiotics (e.g., SCD Odor Away - a completely natural biological odour remover, which contains probiotic microorganisms, antioxidants and enzymes, that inhibit microorganism activity and, thus, odour formation) and 1 time per week deliver to animal by-products' management company (AVAI);

_ separate and produce primary compost by intensive composting with additional energy consumption (in case of technical possibilities).

The price for animal by-product delivery and treatment is up to 4 times higher in comparison with mixed MW; therefore, in case of technical possibilities, the implementation of a personal composting system will allow receiving both the environmental effect (on-site waste reduction) and the economic effect, i.e. saving due to a reduction in the environmental fees for waste management. For example, the implementation of GG 10s (Oklin, BioWaste Technologies) composting equipment in catering, selected for experiment in which about 10 tonnes year-1 of BDW are generated, will allow saving more than 3 thousand EUR year-1 (see Table 3). The payback period will be around 4 years. The economic effect of such an alternative will improve when the volume of BDW increases.

The composting process in 'GreenGood' equipment is carried out with ACIDULO $^{\text {TM }}$ microorganisms to optimise the process and odour elimination. The temperature in the equipment is increased up to $75^{\circ} \mathrm{C}$ for 1 hour to eliminate microbiological-parasitological pollution. Primary compost is produced during 24 hours. Waste reduction depends on primary moisture content and can range from $50 \%$ to $80 \%$ (Oklin, BioWaste Technologies). Air emissions $\left(\mathrm{NH}_{3}, \mathrm{VOC}, \mathrm{CO}\right)$ and $\mathrm{GHG}$ emissions are treated by an activated carbon filter with efficiency from $50 \%$ to $99 \%$ (depending on emission) and supplied to the atmosphere through a ventilation system. The total volume of air emissions will not exceed $0.1 \mathrm{~kg}$ tonne ${ }^{-1}$ of BDW (Eunomia et al., 2002, Boldin et al, 2009). As a result, primary compost is produced. Its maturation during approximately 1-2 months is the second process of compost production, and then the produced high-quality compost can be used for composting purposes within the company. In other EU courtiers, such primary compost can be delivered to centralist GW composting sites for maturation with primary compost made of GW, thereby considerably increasing the value rates of GW compost as a fertiliser.

During further analysis, it was assumed that approximately 0.7 thousand tonnes year ${ }^{-1}$ of BDW (including animal by-products) from catering of Palanga resort could be managed differently than landfilling by using one of the above-mentioned methods. 


\begin{tabular}{|c|c|c|c|c|}
\hline \multirow{2}{*}{$\begin{array}{l}\text { Input and output } \\
\text { flow }\end{array}$} & \multirow{2}{*}{$\begin{array}{l}\text { Current situation (2016) } \\
\text { (animal by-products are } \\
\text { stored and delivered to a } \\
\text { management company) } \\
\text { Units year-1 }\end{array}$} & \multirow{2}{*}{$\begin{array}{l}\text { Planned situation } \\
\text { (after the implementation } \\
\text { of } \mathrm{GG} 10 \text { s composting } \\
\text { equipment) }\end{array}$} & \multicolumn{2}{|c|}{ Savings } \\
\hline & & & Units year ${ }^{-1}$ & EUR year-1 \\
\hline $\begin{array}{l}\text { 'BDW (green food } \\
\text { waste) }\end{array}$ & 3 tonnes & & 3 tonnes & 330.00 \\
\hline $\begin{array}{l}\text { BDW (animal } \\
\text { by-products) }\end{array}$ & 7 tonnes & & 7 tonnes & $3,050.00$ \\
\hline Electricity & ${ }^{22} 2,300 \mathrm{kWh}$ & $35,160 \mathrm{kWh}$ & $-2,860 \mathrm{kWh}$ & -358.00 \\
\hline Compost & ${ }^{4} 0.8$ tonnes & 2 tonnes & - & 128.00 \\
\hline $\begin{array}{l}{ }^{5} \text { Air emissions } \\
\text { (after treatment) }\end{array}$ & - & $1 \mathrm{~kg}$ & $-1 \mathrm{~kg}$ & - \\
\hline \multicolumn{4}{|l|}{ Total savings: } & $3,150.00$ \\
\hline
\end{tabular}

Table 3

Results of feasibility analysis of the implementation of an intensive composting system in a catering company

\section{Notes:}

${ }^{1}$ During the experiment it was evaluated that maximum $30 \%$ of food waste (GW) can be managed as municipal BDW, and the rest as animal by-products.

${ }^{2}$ Animal by-products in a catering company are stored in a separate freezer (Regulation (EU) No 142/2011) (in case of experiment, installed electric capacity of freezer $-0.35 \mathrm{~kW}$ ).

${ }^{3}$ Electricity consumption of GG $10-350-510 \mathrm{kWh} \mathrm{month}^{-1}$ (Oklin).

${ }^{4}$ Compost is used in a cafe for territory greening (swarding).

${ }^{5}$ Activated carbon pellets are easily rinsed with warm water 1 time per month.

According to the data of Palanga waste management plan for 2014-2020, since 2013, 83 sites with SRM containers have been implemented and 23 will be additionally implemented before the year 2020; 1,000 special containers for SRM collection have been distributed for residents of individual holdings for source separation (Palanga WMP, 2014-2020). During the research, it was assumed that during the period 2016-2020 efficiency of source separation of SRM in Palanga resort would increase up to $50 \%$. Therefore, the following amounts of SRM will be collected, prepared for re-use and delivered to recycling companies (e.g., in Klaipeda):

_ paper and cardboard waste and packaging - 700 tonnes per year;

_ glass and glass packaging - 480 tonnes per year;

_ metal and metal packaging - 290 tonnes per year;

_ plastic waste and packaging $-\sim 1,050$ tonnes per year.

The amount of separate fractions of MW after source separation was evaluated using equation (4). The total amount of MW after source separation will be around 12-13 thousand tonnes per year, including over 55\% of BDW (food waste, paper and cardboard waste and packaging, other BDW), approximately $15 \%$ of SRM, and over $16 \%$ of combustible waste. Centralist MW treatment (MT or MBT) could be carried out on the reconstructed territory of the old landfill of Palanga municipality in Joskaudai village (7 km from Palanga) near a newly implemented GW composting site. The following technical alternatives for centralist MW processing were analysed:

1 MT with automatic separation of SRM;

2 MT with semi-automatic separation of SRM;

3 MBT: MT with automatic separation of SRM and BT by tunnel composting;

4 MBT: MT with automatic separation of SRM and BT by container composting;

5 MBT: MT with semi-automatic separation of SRM and BT by container composting. 
The results of environmental impact assessment of all the alternatives show that:

- the implementation of any of the above-mentioned MBT alternatives allows achieving MW and BDW management targets (see Table 1);

_ MBT alternatives have better environmental benefits in comparison with MT: in case of MBT, 9.2-10.7 thousand tonnes year ${ }^{-1}$ of $\mathrm{MW}$ will be diverted from a landfill, including 4-5.2 thousand tonnes year ${ }^{-1}$ of BDW; intensive composting techniques for the processing of BDW fraction are proposed in the MBT alternatives, which allows accelerating the process and minimising air emissions on average up to $98 \%$ and odour (due to implementation of the filtering system).
Feasibility analysis of all the MBT alternatives led to the selection of alternative 5 for implementation. The main steps of such MBT are presented in Figure 2:

- Part of mechanical treatment with total investments 1.18 M EUR, including 21\% of VAT, consists of a loader, MW screening equipment (e.g., Trommel Screen), 2 Fe-magnet separators, semi-automatic separator of SRM (for MW fraction - > $50 \mathrm{~mm}$ ) (e.g., Sutco Recycling Technik), air separator for separation of RDF (refuse-derived fuel) fraction; crusher for RDF fraction $(<30 \mathrm{~mm}$ ), pressing and packaging equipment (for plastic and RDF), and 10 containers for separated SRM;

\section{Fig. 2}

Flowchart of MW centralist separation and biological treatment in Palanga (alternative No 5)

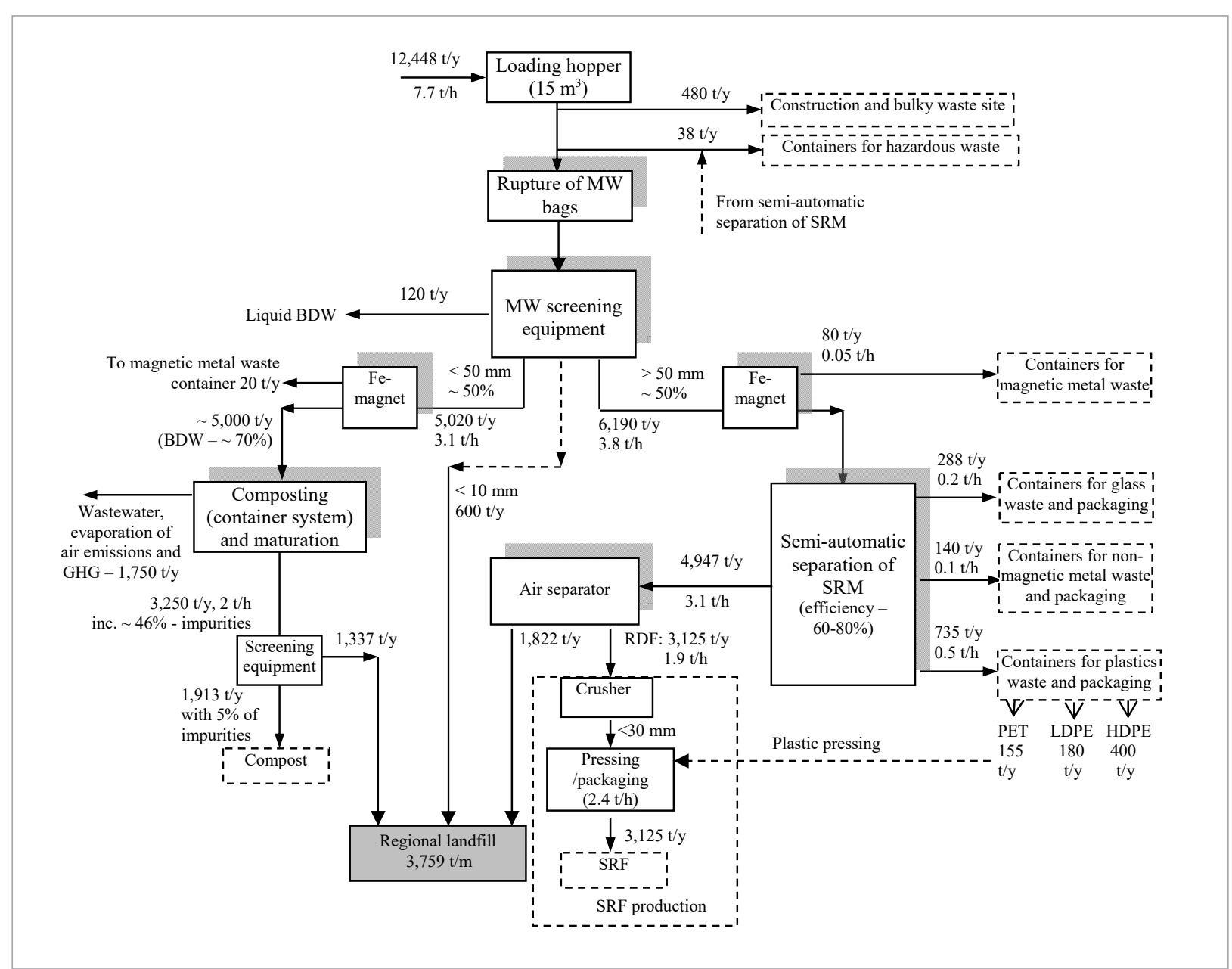

\section{Notes:}

$\mathrm{t} / \mathrm{y}$ - tonnes year ${ }^{-1} ; \mathrm{t} / \mathrm{h}$ - tonnes hour ${ }^{-1}$. 


\begin{tabular}{|c|c|c|c|c|}
\hline \multirow[b]{2}{*}{ MBT inputs and outputs } & \multirow[b]{2}{*}{ Units } & \multicolumn{3}{|c|}{ Situation with MBT (alternative No 5) } \\
\hline & & $\begin{array}{l}\text { Units } \\
\text { year }^{-1}\end{array}$ & $\begin{array}{l}\text { EUR unit }{ }^{-1} \text {, } \\
\text { including } \\
\text { VAT }\end{array}$ & $\begin{array}{c}\text { Expenditures, EUR } \\
\text { year }^{-1} \text { (Incomes), EUR } \\
\text { year }^{-1}\end{array}$ \\
\hline 1 & 2 & 3 & 4 & 5 \\
\hline \multicolumn{5}{|c|}{ Inputs flows: } \\
\hline MW - to MBT equipment & tonnes & & \multicolumn{2}{|c|}{$12-13$ thousand } \\
\hline $\begin{array}{l}1,2 \text { Diesel fuel for MW, inert waste and compost } \\
\text { transportation }\end{array}$ & litres & 5,632 & \multirow{3}{*}{1.20} & \multirow{3}{*}{$12,679.20$} \\
\hline $\begin{array}{l}1,3 \text { Diesel fuel for SRF transportation to 'general waste } \\
\text { combustion' plant in Klaipeda }\end{array}$ & litres & 3,934 & & \\
\hline Fuel consumption for loading equipment (in MBT) & litres & 1,000 & & \\
\hline $\begin{array}{l}\text { Expenditures for drivers for MW, inert waste, compost } \\
\text { and SRF delivering }\end{array}$ & EUR & - & - & $16,011.00$ \\
\hline${ }^{4}$ Electricity consumption & $\mathrm{kWh}$ & 420,000 & 0.127 & $53,176.20$ \\
\hline${ }^{5}$ Personnel (MBT) & employers & 10 & & $139,018.00$ \\
\hline Technical oil consumption & litres & 1,500 & 3.00 & $4,500.00$ \\
\hline Water (for municipal purposes) & $m^{3}$ & 300 & 1.14 & 342.00 \\
\hline \multicolumn{5}{|c|}{ Outputs flows: } \\
\hline${ }^{6} \mathrm{MW}$ to regional landfill & tonnes & 3,159 & 36.37 & $114,893.00$ \\
\hline Inert waste to regional landfill & tonnes & 600 & - & - \\
\hline RDF fraction or SRF to 'general waste combustion' plant & tonnes & 3,125 & 27.68 & $86,500.00$ \\
\hline Construction and bulky waste & tonnes & 480 & 85.00 & $40,800.00$ \\
\hline Hazardous waste, including electronic equipment & tonnes & 38 & 700.00 & $26,000.00$ \\
\hline${ }^{7}$ Technical compost & tonnes & 1,913 & - & $26,283.00$ \\
\hline${ }^{8}$ Plastic (PET, LDPE, HDPE) & tonnes & 735 & - & $58,335.00$ \\
\hline Metal waste (magnetic) & tonnes & 100 & 150.00 & $15,000.00$ \\
\hline Metal waste (package) & tonnes & 140 & 690.00 & $96,600.00$ \\
\hline Glass waste and packaging & tonnes & 288 & 32.00 & $9,216.00$ \\
\hline Used oily wiping, filters, lubricants, oil waste & tonnes & 0.1 & 700.00 & 70.00 \\
\hline${ }^{9}$ Air emissions from mobile sources & tonnes & 2.0 & & 72.31 \\
\hline Water evaporation & tonnes & 1,400 & - & - \\
\hline $\begin{array}{l}\text { Air emissions }\left(\mathrm{NH}_{3}, \mathrm{VOC}, \mathrm{CO}\right) \text { from stationary sources } \\
\text { (after treatment by bio-filter) }\end{array}$ & tonnes & 7.0 & 4.84 & 33.88 \\
\hline Wastewater & $\mathrm{m}^{3}$ & 420 & 1.25 & 525.00 \\
\hline Storm water from open territory ( 0.8 ha) & $\mathrm{m}^{3}$ & 2,352 & & - \\
\hline${ }^{9}$ Storm water pollution (SS, BOD, oil products) & tonnes & 0.142 & & $1,454.54$ \\
\hline${ }^{10}$ Indirect costs & & & & $128,605.00$ \\
\hline \multicolumn{4}{|c|}{ Total direst cost of MW centralist treatment in MBT (including VAT): } & $\begin{array}{l}291,241.00 \text { EUR year }^{-1} \\
23.40 \text { EUR tonne }^{-1}\end{array}$ \\
\hline \multicolumn{4}{|c|}{ Total cost of MW centralist treatment in MBT (including VAT and indirect cost): } & $\begin{array}{l}\text { 419,846.00 EUR year-1 } \\
\text { 33.73 EUR tonne }{ }^{-1}\end{array}$ \\
\hline
\end{tabular}

Table 4

Evaluation of material and energy flows and cost of MW transportation and treatment in MBT 


\begin{abstract}
Notes:
1 Data for evaluation of diesel consumption for MW, compost, and SRF transportation: 14 tonnes of load per trip; diesel fuel consumption 18 litres per $100 \mathrm{~km}$; distances: $70 \mathrm{~km}$ (Palanga - region landfill - Palanga); 7 km (Palanga - MBT site); $42 \mathrm{~km}$ (MBT site - region landfill); $84 \mathrm{~km}$ (Palanga - MBT site - region landfill - Palanga).

${ }^{2}$ Optimal number of trips for MW transportation: 269 units (Palanga - MBT site - region landfill - Palanga) and 621 units (Palanga - MBT site - Palanga), including compost transportation from MBT to Palanga with the total distance $-31,290 \mathrm{~km}$.

${ }^{3}$ Optimal number of trips for SRF transportation: 223 units (MBT site - 'Fortum Klaipeda' Ltd. - Palanga) with the total distance - 21,854 km.

${ }^{4}$ Electricity consumption for mechanical part of MBT - 20 kWh tonne-1 of MW (Eunomia et al., 2002, Boldin et al, 2009); for biological treatment $-\sim 160 \mathrm{MWh}$ year $^{-1}$ for 1 composting module of Biodegma technology.

${ }^{5}$ Personnel: 1 - shift supervisor, 2 - mechanics operators, 8 - employers for manual separation of SRM.

${ }^{6}$ Landfill tax for MW from Palanga resort - 36.37 EUR tonne ${ }^{-1}$, including VAT (since 2016).

${ }^{7}$ Compost produced after the project implementation will replace a part of mould, which is usually purchased by municipality of Palanga town.

${ }^{8}$ Incomes from the sale of extracted plastic were evaluated using the following market prices of SRM: PET - 145 EUR tonne ${ }^{-1}$; LDPE (bags, film) - 87 EUR tonne $^{-1}$; HDPE (milk, detergent bottles) - 43-58 EUR tonne-1.

${ }^{9}$ Tax for emissions: from mobile sources - 9.68 EUR tonne ${ }^{-1}$ of used diesel fuel, including VAT; from stationary sources: $\mathrm{VOC}, \mathrm{CO}$ and $\mathrm{NH}_{3}$ - 4.84 EUR tonne ${ }^{-1}$; wastewater pollution: suspended solids (SS) - 124.63 EUR tonne ${ }^{-1}$, BOD - 305.76 EUR tonne ${ }^{-1}$, oil products - 11895.51 EUR tonne ${ }^{-1}$.

${ }^{10}$ Indirect costs: price for laboratory analysis of produced compost, building and equipment repair (0.5-1\% of investments per year), equipment and building amortisation (period - 15 years), insurance $(0.1 \%$ of investments per year).
\end{abstract}

_ Part of biological treatment with total investments 0.82 M EUR, including VAT, consists of a container composting system (1 module with 8 containers, including one for a bio filter, one for compressed air preparation, fully automatic control) with total BDW processing capacity of 5 thousand tonnes year $^{-1}$ (MW fraction - <50 mm) (e.g., Biodegma)), a tumbler, screening equipment for minimisation of impurities in compost from approximately $45 \%$ to $5 \%$.

Other project investments are directed to construction and building of an MT department $\left(\mathrm{S} \sim 300 \mathrm{~m}^{2}\right)$ with an air ventilation system, a special site for compost maturation $\left(\mathrm{S} \sim 630 \mathrm{~m}^{2}\right)$, designing and building maintenance works. The total project's investments will be approximately 2.15 M EUR, including VAT.

The result of evaluation of material and energy flows and cost of MW treatment due to implementation of MBT (using 2016 prices) is presented in Table 4.

Currently, the direct cost of delivery and disposal of 12.5 thousand tonnes of MW to the region landfill amounts to 479 thousand EUR year-1 (or 38.32 EUR tonne ${ }^{-1}$ of MW), including transportation cost - approximately 24 thousand EUR. The implementation of the suggested MBT will allow saving up to 188 thousand EUR year ${ }^{-1}$. Project's investments will pay back in 12.2 years.
Currently, the price of disposal of combustible fraction of MW (RDF or SRF) to the 'general waste combustion' plant in 'Fortum Klaipeda' Ltd. amounts to over 27 EUR tonne ${ }^{-1}$. If some Lithuanian company, e.g. cement production company 'Akmenés cementas' Ltd., does not take the fee for special prepared SRF, produced from the combustible fraction of MW, the direct cost for centralist MW processing will decrease up to 205 thousand EUR (16.45 EUR tonne ${ }^{-1}$ ), and the payback period will also decrease - to 8.4 years.

Purchase of service of centralist MT of MW could become the economic alternative with the same environmental effect. In this case, project investments will decrease to $0.97 \mathrm{M}$ EUR, including VAT, process direct cost will increase up to 375.7 thousand EUR year ${ }^{-1}$ (over 30 EUR tonne-1), savings will decrease up to 103 thousand EUR year ${ }^{-1}$, and the payback period will decrease to 9.4 years.

Achievable results of waste management in case of implementation of the selected option are presented in Table 5. In case of implementation of the suggested MBT (MT with semi-automatic separation of SRM and BT by container composting), maximum $16.5 \%$ of the total generated MW in Palanga resort and $9.4 \%$ of the total BDW will be disposed. 


\begin{tabular}{l|c}
\hline \multicolumn{1}{c}{ Waste, treated in MBT } & Volume, tonnes year ${ }^{-1}$ \\
\multicolumn{1}{c}{1} & 2 \\
\hline Amounts of MW after source separation, supplied to MBT & 12,448 \\
\hline MW for disposal after MBT (\% of MW to MBT), incl. & 3,159 \\
BDW & $\sim 1,160$ \\
\hline MW, treated by MBT, including & 9,289 including \\
produced technical compost & 1,913 \\
inert waste (for recovering of landfill layers) & 600 \\
RDF production (for combustion) & 3,125 \\
separated plastic (PET, LDPE, HDPE) & 735 \\
separated metal waste (magnetic) & 100 \\
separated metal package waste (non-magnetic) & 140 \\
separated construction and bulky waste & 480 \\
separated hazardous waste, including electronic equipment & 38 \\
separated glass waste and packaging & 288 \\
\hline \hline
\end{tabular}

Table 5

Achievable waste management results due to the implementation alternative with semi-automatic separation of SRF and container composting system

\section{Results of feasibility analysis of sewage sludge management options}

The feasibility study proposes composting sewage sludge (up to 2,500 tonnes year ${ }^{-1}$, including 1,000 tonnes year ${ }^{-1}$ of old one from polygons) together with the GW from public territories. The following 4 technical alternatives for sewage sludge biological processing have been carried out:

1 open composting by using probiotics (compost production);

2 intensive composting by using a container system (compost production);

3 intensive composting by using a container system (compost and SRF production);

4 an aerated windrow cover system (compost production).

The main results of environmental and economical evaluation of all the options are presented in Tables 6 and 7.

Anaerobic treatment of sewage sludge was not analysed in this research due to rather small volume sewage sludge for economic reasoning.

The results of comparative analysis of economical evaluation of service and equipment purchase show that operating costs of composting in purchased equipment for 1 tonne of processed sewage sludge are several times lower compared with service purchase (see Table 7). Therefore, it is proposed to implement own sewage sludge processing equipment. Intensive aerobic sewage sludge treatment with GW in an enclosed system requires more investments compared with open composting. However, closed composting systems have certain advantages against open composting, for example:

- faster first composting period - primary compost production: in case of a container composting system during 14-20 days, and in case of an open composting system up to 2 months during the warm season;

_ closed composting uses less area compared with open composting;

- in case of Palanga, minimum investments are directed to constriction, because the existing sewage sludge storage areas can be used for the compost maturation process and/or storage of produced compost;

- demands less volume of inert materials (in case of a container composting system, up to $50 \%$ of sewage sludge volume, and in case of an open composting system up to $100 \%$ ); 
Table 6

Comparison analysis of material and energy flows of sewage sludge composting options for Palanga resort

\begin{tabular}{|c|c|c|c|c|c|}
\hline \multirow{3}{*}{ Input and output flows } & \multirow{3}{*}{ Units } & \multicolumn{4}{|c|}{4 alternatives } \\
\hline & & 1 & 2 & 3 & 4 \\
\hline & & $\begin{array}{l}\text { Units } \\
\text { year }^{-1}\end{array}$ & $\begin{array}{l}\text { Units } \\
\text { year }^{-1}\end{array}$ & $\begin{array}{l}\text { Units } \\
\text { year }^{-1}\end{array}$ & $\begin{array}{l}\text { Units } \\
\text { year-1 }\end{array}$ \\
\hline \multicolumn{6}{|c|}{ Input flows } \\
\hline Sewage sludge & tonnes & 2,500 & 2,500 & 2,500 & 2,500 \\
\hline GW and biofuel ash & tonnes & 2,500 & 1,250 & 1,250 & 1,250 \\
\hline 'Electricity for composting, screening, pellets production & kWh & 1,250 & 161,000 & 244,840 & 4,750 \\
\hline${ }^{2}$ Diesel fuel for GW transportation & litres & 2,570 & 1,296 & 1,296 & 1,296 \\
\hline Diesel fuel for treatment & litres & 2,000 & 1,000 & 1,000 & 1,000 \\
\hline Personnel & employers & $4-5$ & 2 & 2 & 2 \\
\hline Water (municipal) & $\mathrm{m}^{3}$ & 219 & 90 & 90 & 53 \\
\hline${ }^{3}$ Probiotics & litres & 555 & - & - & - \\
\hline $\begin{array}{l}\text { The filter cartridge (for treatment of emissions from the } \\
\text { composting process ) }\end{array}$ & $\begin{array}{l}\text { unit per } 5 \\
\text { years }\end{array}$ & - & 1 & 1 & 1 \\
\hline Technical oils & litres & - & 350 & 350 & 350 \\
\hline $\begin{array}{l}\text { Natural gas for drying of pre-composting materials (from } \\
\sim 53 \% \text { to } 15 \% \text { of moisture content) }\end{array}$ & $\mathrm{nm}^{3}$ & - & - & 22,000 & - \\
\hline Matrix for granulation process (1 for $800 \mathrm{t}$ of SRF) & unit & - & - & 0.5 & - \\
\hline Additional materials (e.g. raps oil) & tonnes & - & - & 4.48 & - \\
\hline Film (has to be changed times per 5 years) & $m^{2}$ & - & - & - & $700-1,080$ \\
\hline \multicolumn{6}{|c|}{ Output flows } \\
\hline${ }^{4}$ Compost & tonnes & 2,500 & 1,875 & 937.5 & 1,875 \\
\hline${ }^{5} \mathrm{SRF}$ & tonnes & - & - & 406 & - \\
\hline Wastewater (municipal) & $\mathrm{m}^{3}$ & 219 & 90 & 90 & 53 \\
\hline Wastewater after composting & $\mathrm{m}^{3}$ & 2,000 & 1,500 & 1,500 & 1,500 \\
\hline $\begin{array}{l}\text { Air emissions }\left(\mathrm{NH}_{3}, \mathrm{VOC}, \mathrm{CO}\right) \text { and } \mathrm{GHG} \text { emissions from } \\
\text { stationary sources (with or without treatment) }\end{array}$ & tonnes & 500 & 3.75 & 3.98 & 11.25 \\
\hline Air emissions from mobile sources & tonnes & 1.1 & 0.8 & 0.8 & 0.8 \\
\hline $\begin{array}{l}\text { Non-hazardous waste (SM from filters, used membranes, } \\
\text { filtering materials, SRM) }\end{array}$ & & & 10 & 25.06 & 9.32 \\
\hline Hazardous waste & tonnes & - & 0.32 & 0.32 & 0.32 \\
\hline
\end{tabular}

\section{Notes:}

'Electricity consumption: for composting in a container system with the capacity up to 5,000 tonnes year-1 of BDW, e.g., Horstmann technology, up to 160 thousand $\mathrm{kWh}_{\text {year }}{ }^{-1}$; for composting by a cover system, e.g., Biodegma technology, $\sim 1 \mathrm{kWh}$ tonne-1 of composted BDW; for pellets production up to $0.206 \mathrm{kWh} \mathrm{kg}^{-1}$ of pellets; for screening $\sim 0.5 \mathrm{kWh}$ tonne-1 of compost (Kliopova, 2013, EPEM, Kliopova \& Makarskiené, 2013).

2Preliminary distance between Palanga resort and water treatment plant 'Palangos vandenys' Ltd. is $36 \mathrm{~km}$. ${ }^{3}$ For example, the norm for SCD Odor Away probiotics usage for treatment of $1 \mathrm{~m}^{3}$ of sewage sludge: $0.150-0.250$ litres (AVAl). 4Produced compost can be used for growing of energetic plants (LAND 20-2005).

5The low heating value of such SRF (in the pellets' form) is $14.25 \mathrm{MJ} \mathrm{kg}^{-1}$ (Kliopova \& Makarskienè, 2015); such SRF can be combusted in the combined heat and power plant 'Fortum Klaipeda' Ltd., which uses non-hazardous municipal and industrial waste as fuel (e.g., partly replaced bio-fuel). 


\begin{tabular}{|c|c|c|c|c|c|}
\hline \multirow{2}{*}{ Analysed aspect } & \multirow{2}{*}{${ }^{1}$ Unit } & \multicolumn{4}{|c|}{4 alternatives } \\
\hline & & 1 & 2 & 3 & 4 \\
\hline Sewage sludge & tonnes year ${ }^{-1}$ & 2,500 & 2,500 & 2,500 & 2,500 \\
\hline GW & tonnes year-1 & 2,500 & 1,250 & 1,250 & 1,250 \\
\hline Number of composting cycles & units year-1 & 3 & 20 & 20 & $5-9$ \\
\hline $\begin{array}{l}\text { Area, required for composting and } \\
\text { maturation }\end{array}$ & $m^{2}$ & 3,460 & 1,340 & 1,340 & 1,232 \\
\hline Investments in equipment & thousand EUR & $\begin{array}{l}\text { 'service } \\
\text { purchase }\end{array}$ & 832.79 & $1,069.35$ & 445.02 \\
\hline $\begin{array}{l}\text { Investments in building (site for compost } \\
\text { maturation or shed) }\end{array}$ & thousand EUR & 28.04 & 21.03 & 21.03 & 28.04 \\
\hline $\begin{array}{l}\text { Total investments, including design } \\
\text { works, building, construction } \\
\text { supervision, etc. }\end{array}$ & thousand EUR & 28.87 & 854.96 & $1,092.61$ & 473.88 \\
\hline $\begin{array}{l}\text { Manufactured production } \\
\text { - compost for energetic plants' growth } \\
\text { - SRF for combustion in "general waste } \\
\text { combustion" plant }\end{array}$ & tonnes year-1 & $\begin{array}{l}2,500 \\
-\end{array}$ & $\begin{array}{l}1,875 \\
-\end{array}$ & $\begin{array}{l}937.5 \\
406\end{array}$ & $\begin{array}{l}1,875 \\
-\end{array}$ \\
\hline${ }^{3}$ Total operating costs for sewage sludge & $\begin{array}{l}\text { thousand EUR year }{ }^{-1} \\
\text { EUR tonne }^{-1}\end{array}$ & $\begin{array}{l}123 \\
49.37\end{array}$ & $\begin{array}{l}113 \\
45.27\end{array}$ & $\begin{array}{l}142 \\
56.86\end{array}$ & $\begin{array}{l}61 \\
24.50\end{array}$ \\
\hline $\begin{array}{l}\text { Total operating costs for GW (for GW } \\
\text { operator) }\end{array}$ & $\begin{array}{l}\text { thousand EUR year-1 } \\
\text { EUR tonne }^{-1}\end{array}$ & $\begin{array}{l}137 \\
55\end{array}$ & $\begin{array}{l}69 \\
55\end{array}$ & $\begin{array}{l}69 \\
55\end{array}$ & $\begin{array}{l}69 \\
55\end{array}$ \\
\hline $\begin{array}{l}\text { Direct operating costs for sewage } \\
\text { sludge (existing situation in case of its } \\
\text { transportation in 'Klaipedos vandenys' Ltd.) }\end{array}$ & thousand EUR year-1 & 125 & 125 & 125 & 125 \\
\hline $\begin{array}{l}\text { Direct operating costs for sewage sludge } \\
\text { (planned situation) }\end{array}$ & thousand EUR year-1 & 121 & 47 & 57 & 24 \\
\hline Savings & thousand EUR year-1 & 4 & 78 & 68 & 101 \\
\hline Payback period & years & - & 11 & 16.1 & 4.7 \\
\hline
\end{tabular}

Table 7

Results of economical evaluation of the analysed sewage sludge management options

\section{Notes:}

${ }^{1}$ All economic indicators are presented with $21 \%$ of VAT.

${ }^{2}$ Average service price according to the proposals of 3 companies - 60 EUR tonne $e^{-1}$ of sewage sludge, including VAT (2016). ${ }^{3}$ Total operating costs for sewage sludge consist of direct expenditures, calculated according to the data of Table 6, and indirect, e.g. price for laboratory analysis of produced compost and SRF, building and equipment repair (0.5-1\% of investments per year), equipment and building amortisation (period 15 years), insurance ( $0.1 \%$ of investments per year), excluding income from manufactured production (12.10 EUR tonne ${ }^{-1}$ of compost, 50.82 EUR tonne $^{-1}$ of SRF).

_ existing GW management costs will be reduced (see Table 7):

_ composting takes place in a fully enclosed system; therefore, the risk of odour and untreated air emissions will be minimised;

_ air emissions are treated in bio-filters up to $98-99 \%$;

_ the process is fully automated; therefore, 2 employers are enough for operating;

- etc.
Although the forth alternative has the best economical results (see Table 7), the operator decided to choose the container composting system because of the following disadvantages of alternative No. 4: the composting time is 2.5 times longer (up to 40 days), and the cover requires changing (approximately once in 5 years).

The evaluation of the third alternative for Palanga resort sewage sludge management was based on the re- 
search which was done when implementing one stage of the FP7 program project 'Polygeneration of energy, fuels and fertilizers from biomass residues and sewage sludge' (ENERCOM). During the research, different compositions of compost, which is produced in the company 'Soil-Concept' (Luxembourg), were used. Compost is made of sewage sludge after anaerobic treatment and of different types of green waste and other biomass residuals. The laboratory analysis showed that fractions 10-40 mm of pre-composted materials characterised a rather good energetic calorific value and could be used for SRF production, while other fractions could be used for further composting (maturation, sieving, etc.) and compost production. Besides, during the first composting process, moisture content naturally decreases from $80 \%$ to $50-40 \%$ (Kliopova \& Makarskiene 2012, 2013). The main results of the applied research analysing possibilities of SRF production in Palanga wastewater treatment plant are as follows (Kliopova \& Makarskienè, 2015):

_ moisture content of pre-composted materials ( $\sim 50 \%$ of dewatering sewage sludge, $\sim 50 \%$ of green waste from public territories) is $\sim 53 \%$;

_ carbon content in dry matter of the pre-composted materials amounts to over $37 \%$;

_ the net calorific value of SRF with $15 \%$ of the moisture content amounts to $14.25 \mathrm{MJ} \mathrm{kg}^{-1}$ and corresponds to the net calorific value of the biofuel widely used for heat energy production in Lithuania;

_ preliminary ash content is $20.57 \%$ (over $45 \%$ less in comparison with dry sewage sludge);

_ according to the SRF Classification CEN/TC 343, by the net calorific value SRF contributes to class 4 , by the chlorine content in dry matter $(0.016 \%)$ to class 1 , and by mercury content $\left(0.042 \mathrm{mg} \mathrm{MJ}^{-1}\right)$ to class 3 (CEN/TC 343);

- according to the energy balance, obtained during SRF production and combustion, the efficiency of energy recovery is up to 0.86 , i.e., over $30 \%$ bigger than in case of energy recovery from $\mathrm{MW}$ in waste incineration plants (0.65) (Quiroga et al., 2010);

- for the purpose of reducing the environmental impact on air, pre-composted materials can be mixed with sawdust (up to $10 \%$ of the total SRF raw materials volume).

\section{Main results of implementation of the integrated waste management system in Palanga resort}

The expected results of implementation of the suggested integrated waste management system (IWMS) in Palanga resort for 2020 are presented in Fig. 3. The following options are suggested for the IWMS of Palanga resort after the feasibility analysis of all the waste management alternatives:

1 Improvement of existing source separation and processing of BDW:

_ in case of individual households: separation of BDW, including food GW and home composting, using composting bins;

- in case of catering companies, accommodations, kindergartens, schools, etc.:

- separation of BDW, including animal by-products, storage in special tanks using probiotics for elimination of odour emissions and delivery to an animal by-products' management company or

- separation of BDW, including animal by-products and composting by an intensive composting system (hereby, significantly minimising the volume of BDW and eliminating microbiological pollutions) and use of compost for own purposes or delivery of the primary compost to a centralist GW composting site for maturation with GW primary compost and, thus, for improving its quality characteristics;

2 Centralist processing of MW after source separation by MBT equipment (in the territory of an old dump), including MT with semi-automatic separation of SRM and BT by container composting;

3 Intensive composting of sewage sludge (newly generated with old ones from polygons) and part of GW from public territories of Palanga resort, using an aerated windrow cover system or a container system (depending on investment possibilities) in the territory of the wastewater treatment plant. In case of minimisation of demand of such compost, an SRF production system (palletising equipment, etc.) can be implemented.

The implementation of the suggested options and previously planned methods for SRM source separation 


\section{Fig. 3}

The integrated waste management system (IWMS) of Palanga resort

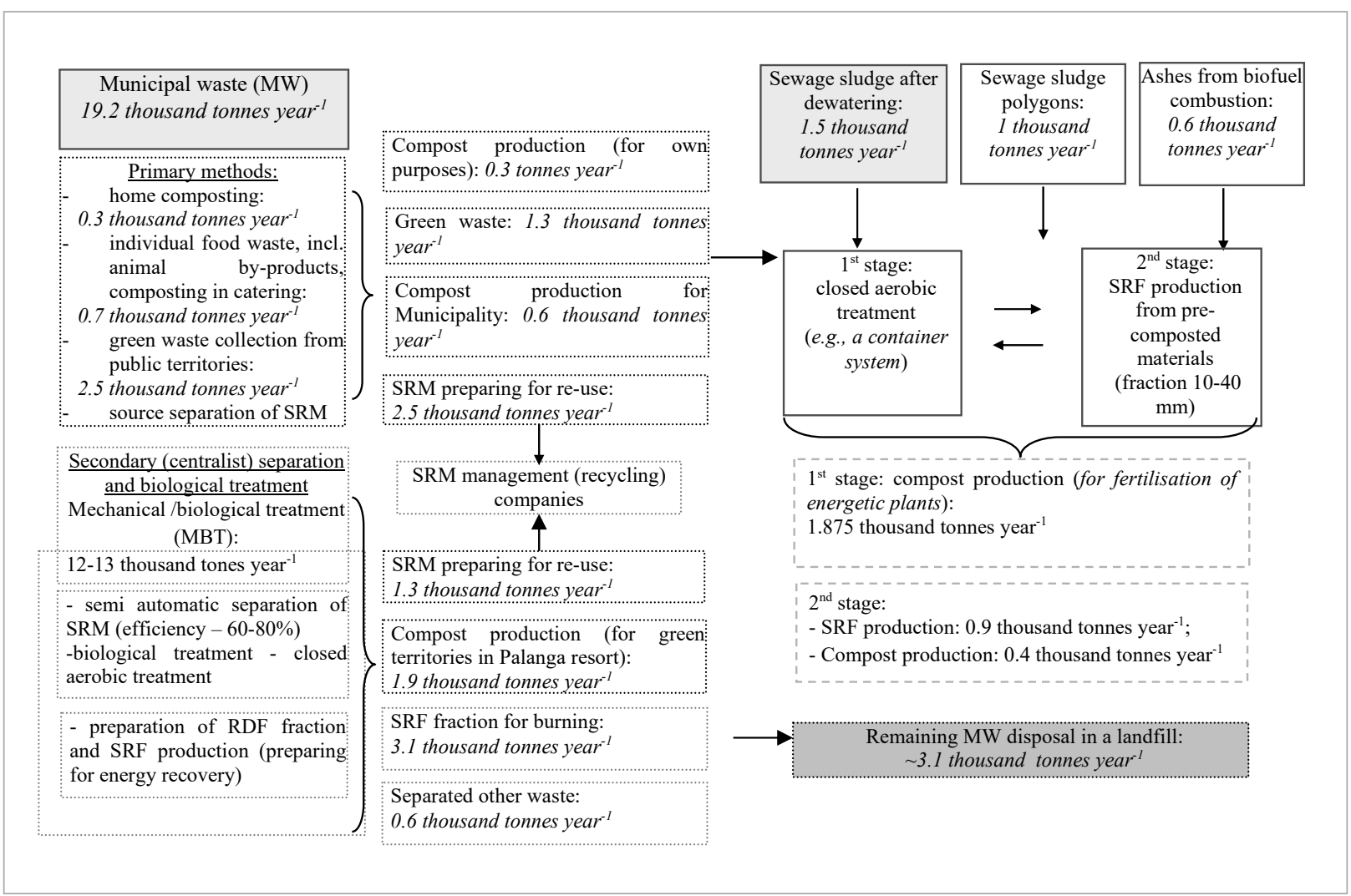

will allow managing 19.1 thousand tonnes year ${ }^{-1}$ of the generated waste, including MW by means different than landfilling. That makes over $85 \%$ of the total degenerated waste in Palanga resort.

The options of an IWMS are specifically suitable for Palanga resort because of the following reasons:

- The distance from the resort town to the regional MW landfill site and to the sewage sludge treatment place increases the costs of such waste delivery;

_ BDW makes more than $50 \%$ of the total MW; SRM over 25\%;

- The total heavy metal concentration in sewage sludge is up to 2.1 times lower than that of sewage sludge in other EU countries;

- The suggested options of an IWMS correspond to the waste management hierarchy, since more than $85 \%$ of the waste, generated in this municipality, will be treated differently than landfilling: waste will be converted to a product, recycled, and prepared for reuse or recovery;

- The landfill tax shows an increasing tendency; the amount of municipal waste generated per capita in Palanga resort is 2-3 times higher than the EU average, as the per capita up to 30 tourists; therefore, the application of the landfill tax considerably increases municipal waste management costs for local residents;

The implementation of options of an IWMS in Palanga resort will allow receiving the main social benefits:

_ the cost of MW delivery and disposal for local residents could decrease by 1.2-2.3 times (depending on an RDF disposal price); besides, its dependence on the landfill tax will also decrease; _ the cost of sewage sludge processing will decrease to 2.6 times and reduce the total cost of wastewater treatment service; 
- Palanga is a resort, visited by many tourists, including foreigners; therefore, the implementation of the options of an IWMS will allow increasing the prestige of the resort in the area of environmental performance and social responsibility.

\section{Conclusions}

The main part of the waste generated in resort cities (over 95\%) is MW from households and other origins similar to households, food waste, including animal by-products, from catering and accommodation companies, GW from public territories and sewage sludge with an inconsiderable amount of heavy metals. BDW makes over $50 \%$ of all the waste. The amount of MW generated per capita in resort cities is several times higher than in other towns, as the per capita up to a few dozens of tourists; therefore, the application of the landfill tax considerably increases MW management cost for local residents.

In accordance with the Waste Framework Directive, the following priority has to be applied in the waste management activity: (0) waste prevention (non-waste), (1) preparing for re-use, (2) recycling, (3) recovery and (4) disposal. Waste has to be managed without endangering human health and the environment. Until 2020, minimum $50 \%$ of waste has to be re-used and recycled. Only separated MW, which characterises a sufficient calorific value, has to be used for energy recovery. While it is understood that source separation of SRM, BDW and other waste of MW is the best available method for waste preparation for re-use and optimal processing, a considerable amount of such waste is rested in MW flow and landfilling or, at best, burning for energy production. Therefore, centralist processing for additional separation of SRM, BDW, and RDF fraction is the second method for the integrated approach for municipal waste management. In particular, the integrated approach could be applied in small resort cities, where a number of disturbances hinder an increase in the efficiency of source separation by more than 50\%, especially BDW; they include insufficient vacant land for sorting containers, high cost of land, no technical possibilities for more frequent collection of municipal BDW, especially during the tourist season, etc.
The main disturbances for sewage sludge management are rather big costs of sewage sludge transportation to newly implemented plants (in the centres of regions). Due to this fact, part of sewage sludge, generated in wastewater treatment plants of smaller towns, including resorts, used to be stored in polygons. In accordance with Lithuanian NWMP for 2014-2020, the accumulation of urban sewage sludge in polygons was stopped in 2015 .

The results of this research provide some management options for the compensation of the above-mentioned disturbances for Palanga resort and minimising volume of landfilled waste:

_ up to 300 tonnes year ${ }^{-1}$ due to improvement of existing source separation of GW in individual households by the implementation of composting bins;

_ up to 700 tonnes year ${ }^{-1}$ due to source separation of BDW, including animal by-products, and composting by an intensive composting system in catering and accommodation companies;

- up to 9.3 thousand tonnes year-1 due to implementation of centralist processing of $\mathrm{MW}$ after source separation by MT with semi-automatic separation of SRM and BT by container composting.

Intensive composting of sewage sludge with GW from public territories of Palanga resort will allow scientifically decreasing concentrations of heavy metals in produced compost, eliminating microbiological pollutions, and decreasing direct costs of sewage sludge management.

It is expected that only $14 \%$ of the generated waste in the analysed resort town will be disposed in a landfill after the implementation of the suggested IWMS. Most of the waste will become new products or raw materials for production of new products. As much as $85 \%$ of BDW, including green waste and sewage sludge, will be used for compost production and fertilisation of green territories in Palanga and for growth of energetic plants. Moreover, in the nearest future, alternative energy fuel - SRF - can be produced from part of pre-composted materials.

Certain solutions of the suggested integrated waste management system can be successfully used in other resorts as well. 


\section{Acknowledgements}

The paper presents part of the results of the feasibility study Development of biodegradable waste management system in Palanga town municipality, which was carried out when implementing one stage of the RECO Baltic 21 Tech project, partly funded by the Baltic Sea Region Programme 2007-2013 (RECO Baltic 21 Tech project).

\section{References}

Amlinger, F. Peyr, S. \& Cuhls, C. (2008) Greenhouse gas emissions from composting and mechanical biological treatment. Waste Management and Research: 26, 47-60.

Berghel, J., Renström, R. (2003) Basic design criteria and corresponding results performance of a pilot-sc fluidized superheated atmospheric condition steam dryer. Biomass\&Bioenergy 23: 103-212.

Boldrin, A., Andersen, J.K., Moller, J., Christensen, T.H., Favoino, E. (2009). Compost and compost utilization: accounting of greenhouse gases and global warming contributions. Waste Management and Research 27: 800-812.

Busca, G., Pistarino C. (2003) Technologies for the abatement of sulphide compounds from gaseous stresams: a comparative overview. Journal of Loss Prevention in the Process Industries: 16: 363-371.

Cadena, E, Colon, J., Artola, A., Sánchez, A., Font, X. (2009) Environmental impact of two aerobic composting technologies using life cycle assessment. J Life Cycle Assess 14: 401-410.

Clemens, J., Cuhls, C. (2003) Greenhouse gas emissions from mechanical and biological waste treatment of municipal waste. Environmental Technology 24(6): 745-754.

Cukjati, N., Zupančič, G. D., Roš, M., Grilc, V. (2012) Composting of anaerobic sludge: An economically feasible element of a sustainable sewage sludge management. Journal of Environmental Management 106: 48-55.

Gujer, W., Zehnder A. J. B. (1983) Conversion Processes in Anaerobic Digestion. Water Science \& Technology 15 (8-9): 127-167.

van Haandel and J. van der Lubbe (2007) Biological Waste Water Treatment. Handbook: 377-398.

Holmberg, H. (2007) Biofuel Drying as a Concept to Improve the Energy Efficiency of an Industrial CHP Plant. Dissertation. Helsinki University of Technology (Espoo, Finland): 58.
Besides, the author thanks public institution Institute of Environment Management and Audit (AVAI), BioWaste Technology Ltd., and Biastra plius Ltd., for technical support (submission of technical data for feasibility analysis of waste management alternatives).

Houdkova, L., Boran, J., Ucekaj, V, Elsaber, T \& Stehlik P. (2008) Thermal processing of sewage sludge II. Applied Thermal Engineering 28: 2083-2088.

Ye, W., Han, J., Qin, L., Li, Y., Masami, F., Yao, H. (2012) Emission characteristics of PM10 during sewage sludge combustion. Aerosol and Air Quality Research 12: 420-425.

Karagiannidis, A., Perkoulidis, G. (2009) A multi-criteria ranking of different technologies for the anaerobic digestion for energy recovery of the organic fraction of municipal solid wastes. Bioresource Technology 100 (8): 2355-2360

Kliopova, I. (2013) Feasibility study. Development of biodegradable waste management system at Palanga town municipality. Applied scientific work: 149.

Kliopova, I., Makarskienè, K. (2012) Generation of Solid Recovered Fuel from Sewage Sludge Compost. Environmental Research, Engineering \& Management 4(62): 39-42.

Kliopova, I., K. Makarskienè, K. (2013). Generation of Solid Recovered Fuel from the Separate Fraction of Pre-composted Materials (Sewage Sludge and Biomass Residues). Environmental research, Engineering and Management 2(64): 5-18.

Kliopova, I., K. Makarskienè, K. (2015). Improving material and energy recovery from the sewage sludge and biomass residues. Waste Management 36: 269-276.

Kliopova, I., Stanevičiūtè, K. (2013) Evaluation of Green waste Composting Possibilities. Environmental Research, Engineering and Management 3(65): 6-19.

Li, H., Chen, Q., Zhang, X., Finney, K.N., Sharifi, V. N., Swithenbank, J. (2011) Evaluation of a biomass drying process using waste heat from process industries: a case study. Biomass drying 2.

Magdziarz, A., Werle, S. (2014) Analysis of the combustion and pyrolysis of dried sewage sludge by TGA and MS. Waste Management 1(34): 174-179. 
Monnet, F. (2003) An Introduction to Anaerobic Digestion of Organic Wastes. Final Report: 48.

Obernberger, I., Brunner, T. \& Polzer, A. (2009) Generation of raw materials: report on input fuel analysis. ENERCOM. BIOS. Publishable summary: 43.

Quiroga, G., Castrillon, L., Fernandex-Nava, Y., Maranon, E. (2010) Physico-chemical analysis and calorific values of poultry manure. Waste Management 5(30): 880-884.

Spets, J.P., Ahtila, P. (2004) Reduction of organic emissions by using a multistage drying system for woodbased biomass. Drying Technology 22: 541-561.

Staugaitis, G., Mažeika, R., Antanaitis, A., Antanaitis, Š. (2011) Analysis and evaluation of quality requirements of compost used in agriculture. Applied scientific work: 83. Available at: https://zum.lrv.lt/uploads/zum/documents/files/ LT_versija/Veiklos_sritys/Mokslas_mokymas_ir_konsultavimas/Moksliniu_tyrimu_ir_taikomosios_veiklos_darbu_galutines_ataskaitos/0darbasKompostoataskaita2011.pdf (accessed April 2012).

Staugaitis, G., Vaišvila, Z. (Executive Editors) (2015) Innovative solutions of soil and agro chemistry science. Agrochemical Research Laboratory of the Lithuanian Research Centre for Agriculture and Forestry (LAMMC ATL). Monography: 319

Velis, C.A., Longhurst, P.J., Drew, G.H.,Smith, R., Pollard, S.J.T. (2009) Biodrying for mechanical-biological treatment of wastes: A review of process science and engineering. Bioresource Technology 100 (11): 2745-2761.

Wetle, S., Wilk. R. (2010) A review of methods for the thermal utilization of sewage sludge: the Polish perspective. Renewable Energy 35: 1914-1919.

Wzorek, M. (2012) Characterisation of the properties of alternative fuels containing sewage sludge. Fuel Processing Technology 104: 80-89.

Xiao, H., Ma, X., Liu, K. (2010) Co-combustion kinetics of sewage sludge with coal and coal gangue under different atmospheres. Energy Conversion and Management 51: 1976-1980.

\section{Other information sources:}

BIODEGMA. Available at: http://www.biodegma.de/ (accessed January 2012).

BEKON Energy Technologies. Available at: http://www.becon. eu/dry-fermentation.html (accessed January 2012).

Biotechnologies. AVAI. Available at: http://www.avai.lt/index. php/lt/probiotikai.html (accessed July 2016).
Biodegradable waste processing. Biastra Plius. Available at: http://biastraplius.lt/lt/ (accessed January 2012).

BioWaste technologies. Available at http://www.bwt.lt/ (accessed January 2012).

Commission Regulation (EU) No 142/2011 of 25 February 2011 implementing Regulation (EC) No 1069/2009 of the European Parliament and of the Council laying down health rules as regards animal by-products and derived products not intended for human consumption and implementing Council Directive 97/78/EC as regards certain samples and items exempt from veterinary checks at the border under that Directive Text with EEA relevance. Available at: http://eur-lex.europa.eu/legal-content/EN/ ALL/?uri=CELEX\%3A32011R0142 (accessed March 2016). ELI: http://data.europa.eu/eli/reg/2011/142/oj

Directive 2008/98/EC of the European Parliament and of the Council of 19 November 2008 on waste and repealing certain Directive (Waste Framework Directive (WFD). Available at: http://eur-lex.europa.eu/LexUriServ/LexUriServ.do?uri=0J:L:2008:312:0003:0030:en:PDF (accessed April 2012).

Eunomia (2002) Financing and incentive schemes for municipal waste management. Case studies. Final Report to DG Env, European Commission. Available at: http://ec.europa.eu/ environment/waste/studies/financingmunicipalwaste_management.htm (accessed October 2015).

European Committee for Standardization (ed.), 2011. Solid recovered fuels - Specifications and classes. Technical Committee 343 Solid Recovered Fuels (CEN TC 343). CEN/TR 15359:2011.

EUROSTAT. Waste generation and treatment. Available at http://ec.europa.eu/eurostat/web/environment/waste/ main-tables (accessed August 2016).

Environmental Planning, Engineering \& Management. Database of Waste Management Technologies. Available at http:// www.epem.gr/waste-c-control/database/default.htm (accessed August 2015).

GORE $^{\circledR}$ Cover For Organic Waste Treatment. Available at: https://www.gore.com/products/gore-r-cover-for-organicwaste-treatment (accessed April 2012).

LAND 20-2005. Requirements of sewage sludge usage for fertilization and restoration, approved by Ministry of Environmental of the Republic of Lithuanian (2005) (last addition 28-07-2016 No. D1-517). Available at: https://e-seimas.Irs.lt/ portal/legalAct/lt (accessed 1 August 2016) 
Lithuanian National Waste Management Plan for 2014-2020, approved by Resolution of the Government of the Republic of Lithuania (No.366, 16-04-2014). Available at: https://e-seimas.lrs.lt/portal/legalAct/lt (accessed January 2015).

Oklin Intelligent food composting solutions. Available at http://oklininternational.com/technology/ (accessed January 2016)

Palanga Waste Management Plan for 2014-2020, approved by Palanga Town Council (No. T2-288, 30-09-2014). Available at: http://www.palanga.lt/vaktai/Default.aspx?ld=3\&Docld=26231 (accessed 1 August 2016).

RECO Baltijos-21 Tech project. Available at: http://www.recobaltic21.net/lt.html (accessed January 2012).

Regulation (EC) No 1069/2009 of the European Parliament and of the Council of 21 October 2009 laying down health rules as regards animal by-products and derived products not intended for human consumption and repealing Regulation (EC) No 1774/2002 (Animal by-products Regulation). Available at: http://eur-lex.europa.eu/legal-content/EN/ALL/?uri=CELEX\%3A32009R1069 (accessed March 2016).

http://data.europa.eu/eli/reg/2009/1069/oj

Waste management plant of Klaipeda region, approved by Development Council of Klaipeda Regional (18-11-2014, No. 51/3S-27). Available at http://www.kratc.lt (accessed July 2016).

Waste management in Palanga municipality. Available at: http://www.palanga.lt/index.php?1941336568 (accessed December 2013).

\section{About author}

\section{Dr. IRINA KLIOPOVA}

Assoc. prof., Institute of Environmental Engineering, Kaunas University of Technology.

Main research area(s): industrial sustainable development, biodegradable waste management, optimisation of technological processes through improvement of environmental performance, cleaner production and resource efficiency, environmental impact assessment.

Address: K. Donelaičio 50, LT-44239 Kaunas, Lithuania, tel.: +370 687 49877, e-mail: irina.kliopova@ktu.lt 


\section{Integruoto atliekų valdymo sistema kurorto miestui}

\section{Irina Kliopova}

Kauno technologijos universitetas, Aplinkos inžinerijos institutas

K. Donelaičio g., 50-308, 44239 Kaunas, Lietuva

Europos Parlamento ir Tarybos direktyvoje 2008/98/EB Dèl atlieku didelis dèmesys skiriamas kriterijams, pagal kuriuos atliekas reikètų analizuoti kaip išteklius. Stengiamasi užtikrinti kuo aktyvesni atliekų perdirbimą, didinant aplinkos apsaugos veiksmingumą ir ekonomini efektyvumą. Direktyvoje nurodoma, kad poveikio aplinkai mažinimo priemones turi būti taikomos viso produktų būvio ciklo metu, issk. atlieku tvarkymą ir pabrěžiama, kad atliekų deginimą reiketų taikyti tik nuo mišraus srauto atskirtoms degioms ir kaloringoms atliekoms.

Nuo 2008 metu visos ES valstybės narès parengè arba atnaujino atliekų tvarkymo planus, kuriuose numatè pagrindinius uždavinius ir priemonès atlieku prevenciniai, mažinimui ir saugiam antriniam panaudojimui, taikant Švaresnès gamybos taršos prevencijos metodus ir maksimaliai išnaudojant susidariusių atlieku medžiagines ir energetines savybes. Ypatingas demėsis skiriamas komunaliniu atlieku (KA) valdymo sprendimams. 2014 m. ES-28 šalyse vidutiniškai vienas žmogus sugeneravo 474 kg mišriu KA, tik 27 proc. KA - pašalinti sąvartynuose (Eurostat, 2016). Lietuvoje dar $2011 \mathrm{~m}$. sąvartynuose buvo šalinama virš 77 proc. KA, 2014 m. - 58.59 proc. ir šis rodiklis turi gerokai sumažeti iki 2020 metu.

Pastaraji dešimtmeti Lietuvoje dedama labai daug pastangu tam, kad sumažinti sąvartynuose šalinamu atliekų kieki:

- biologiškai skaidžiu atlieku (BSA) atveju: irengtos 54 žaliuju atlieku (ŽA) kompostavimo aikštelès, 21 centralizuotas komunalinių nuoteku valymo irenginiu dumblo apdorojimo irenginys, $10 \mathrm{KA}$ centralizuoto apdorojimo irenginių; regiono atliekų tvarkymo centrai individualių namų gyventojams išdalino nemažai ŽA kompostavimo děžių;

- kitu atlieku atveju: kiekviename mieste irrengtos antriniu žaliavu, didžiujjų atliekų, pavojingu atlieku aikštelès; $2016 \mathrm{~m}$. vasario mèn. pradejjo veikti užstato sistema; kt.

Integruoto atlieku valdymo sistema (IAVS) Palangos miesto savivaldybei buvo pasiūlyta, vykdant RECO Baltijos-21 Tech projektą (2011-2013) (RECO Baltijos-21 Tech). 2015-2016 metais tyrimas buvo pratęstas tikslu kavinems bei apgyvendinimo istaigoms pateikti sprendimus BSA, isk. šalutinius gyvulinius produktus (ŠGP) optimaliam tvarkymui bei pasiūlyti geriausiai prieinamą būdą centralizuotam KA po pirminio rūšiavimo tvarkymui, gerokai padidejus atlieku tvarkymo ikkainiams (KA priemimo i regionini nepavojingu atlieku sąvartyną ir žaliuju atliekų kompostavimo aikšteles).

Tyrimo metu nustatyta, kad kurortiniuose miestuose atliekų tvarkymo sistema stipriai skiriasi nuo kitu miestu dèl eilès priežasčių: virš 95 proc. atlieku - KA, isk. iš kavinių bei apgyvendinimo istaigu, kurios savo sudetimi panašios i mišriuju KA srautą, bet jose vyrauja BSA, isk. ŠGP; didele priklausomybe nuo sezoniškumo; kurortų ir kitos apsaugos zonos, pvz., rekreacinès zonos, Natura 2000 bei kitos gamtos saugojimo teritorijos, kuriose atliekų tvarkymo (perdirbimo) veikla neimanoma (atliekos turi būti išvežamos); pirminio rūšiavimo apribojimai (mažai laisvu savivaldybėms priklausomų plotų; sunkus transporto privažiavimas; labai dideli žemès mokesčiai; kt.); virš 50 proc. mišriuju KA - BSA, kurių biodegradavimas uždaruose KA konteineriuose prasideda labai greitai, ypatingai turistiniu šiltuoju sezono metu (dèl kvapu susidarymo KA konteinerių ištuštinimas turi būti vykdomas dažniau, del to ženkliai padideja bendri mišriuju KA tvarkymo 
kaštai); vienam kurortinio miesto gyventojui dèl didelių turistu srautų tenka kelis kartus didesnis KA bei nuotekų kiekis, palyginti su kitu miestu gyventojais; todèl išlaidos už KA tvarkymą bei nuotekų valymą būna žymiai didesnès; Palangos miesto savivaldybės atveju nuotekų tvarkymo kaina gali padidèti ir dèl kitos priežasties - didejjančios išlaidos dumblo transportavimui ir pridavimui centralizuoto apdorojimo irenginiui Klaipèdoje.

Tyrimo metu pasiūlytos IAVS sprendimu realizavimas leistų kompensuoti minètus trikdžius, taip pat sumažinti sąvartyne šalinamų atliekų kieki:

_ pagerinus pirmini BSA rūšiavima:

_ iki 300 tony per metus dè ŽA, isk. maisto ŽA kompostavimo individualiuose valdose, pvz., kompostavimo děžèse, gaminant geros kokybès kompostą ir ji naudojant nuosaviems reikmèms;

_ iki 700 tonu per metus del BSA, isk. ŠGP tinkamo tvarkymo kavinèse arba apgyvendinimo istaigose:

_ surenkant specialiuose konteineriuose, kvapu prevenciniai naudojant probiotines medžiagas ir saugiai perduodant ŠGP tvarkytojams arba

_ esant techninėms galimybėms, kompostuojant uždaruose intensyvaus kompostavimo irenginiuose taip žymiai sumažinant kieki, eliminuojant mikrobiologinę taršą bei gaminant aukštos kokybès kompostą nuosaviems reikmèms arba pirmini kompostą, kuri galima perduoti ŽA kompostavimo aikštelems brandinimui kartu su ŽA pirminiu kompostu taip gerinant pastarojo kokybès rodiklius;

_ iki 9.3 tūkst. tony per metus ¿̇diegus centralizuoto apdorojimo įrenginius: mechaninio apdorojimo su pusiau rankiniu antrinių žaliavu atskyrimu (efektyvumas iki 60-80 proc.) bei konteinerinę intensyvaus kompostavimo sistemą;

_ intensyvus nuoteku dumblo kompostavimas (naudojant konteinerinę sistemą arba sistemą su priverstiniu oro padavimu ir uždengimu plèvele) kartu su ŽA leistu gaminamame komposte ženkliai sumažinti sunkiuju metalu koncentracijas, eliminuoti mikrobiologinę / parazitologinę taršą bei, tokiu būdu, padidinti komposto realizavimo galimybes.

IAVS sprendimu dèka tik 14\% savivaldybeje generuojamy atlieku (didžioji galis - kitos nedegios KA) būtu nukreipta į regionini sąvartyną šiltinimui. Pagrindinè dalis atlieku taptu naujais produktais arba antrinemis žaliavomis nauju produktų gamybai. Pavyzdžiui, 85\% BSA, isk. ŽA ir nuotekų dumblą, būtų naudojamos ¡vairių kompostų gamybai. Sumažejjus komposto iš dumblo poreikiui, darbe ivertinta galimybè su nedidelemis papildomomis investicijomis pradèti gaminti kietaji atgautaji kurą.

IAVS sprendimai kurortinio miesto gyventojams sumažintų mokesčius už atliekų tvarkymą, padidintų miesto prestižą socialinès atsakomybès ir aplinkosaugos veiksmingumo didinimo srityse.

Dauguma iš pasiūlytų IAVS sprendimu gali būti sèkmingai naudojami ir kitose kurortiniuose miestuose. 